\title{
Enhanced transduction of mouse bone marrow- derived dendritic cells by repetitive infection with self- complementary adeno-associated virus 6 combined with immunostimulatory ligands
}

\author{
WA Aldrich ${ }^{1,2}$, C Ren ${ }^{3}$, AF White ${ }^{3}$, S-Z Zhou ${ }^{4}$, S Kumar ${ }^{3}$, CB Jenkins ${ }^{1,2}$, DR Shaw ${ }^{1,2}$, TV Strong ${ }^{1,2}$, \\ PL Triozzi ${ }^{1,2}$ and S Ponnazhagan ${ }^{2,3}$ \\ ${ }^{1}$ Department of Medicine, The University of Alabama at Birmingham, Birmingham, AL, USA; ${ }^{2}$ The Comprehensive Cancer Center, The \\ University of Alabama at Birmingham, Birmingham, AL, USA; ${ }^{3}$ Department of Pathology, The University of Alabama at Birmingham, \\ Birmingham, AL, USA and ${ }^{4}$ Avigen Inc., Alameda, CA, USA
}

\begin{abstract}
The potential of adeno-associated virus (AAV)-based vectors in human gene therapy is being explored for several diseases. Although sustained transgene expression and low vector-associated cellular immunity are attractive features of recombinant (r) $A A V$, the wider application of $r A A V$ vectors encapsidated in serotype 2 capsid is hampered by poor transduction efficiency in many target tissues. These include ex vivo-generated dendritic cells (DC), which have demonstrated promising immunotherapeutic activity. We report here that efficient transduction of mouse bone marrow-derived DC can be achieved with self-complementary (sc) rAAV encapsidated in serotype 6 capsid. Sequential exposure of DC precursor cultures to IL-4 and GM-CSF with sc rAAV6 encoding the human tumor antigen, carcinoembryonic antigen (CEA), for 7 days followed by activation with CpG oligodeoxynucleotides (ODN) and anti-mouse CD40 antibody resulted in highly efficient transduction of DC. DC surface markers as determined by flow cytometry analysis
\end{abstract}

of SC rAAV6-transduced DC were comparable to nontransduced DC. Efficiency of vector transduction and transgene expression were confirmed by immunostaining and real-time PCR. Microarray analysis of RNA from CpG ODN and CD40 antibody stimulated Sc AAV6-transduced DC revealed upregulation of transcription factors and cytokines involved in immune activation and downregulation of inhibitory factors, suggesting a possible role of transcriptional activation in the observed effect. The adoptive transfer into syngeneic mice of the ex vivo-transduced and activated DC resulted in the development of CEA-specific antibody and T-helper 1-associated immune responses. Immunized mice also developed antibody to AAV6 capsid protein, which did not crossreact with AAV2 capsid protein. These studies demonstrate the potential utility of sc $r A A V$ serotype 6-based vectors in transduction of $D C$ for genetic vaccination approaches.

Gene Therapy (2006) 13, 29-39. doi:10.1038/sj.gt.3302601; published online 1 September 2005

Keywords: adeno-associated virus; carcinoembryonic antigen; dendritic cell; self-complementary genome

\section{Introduction}

Adeno-associated virus (AAV) is emerging as a potential alternative vector for human gene therapy. ${ }^{1-3}$ Based on its unique features including stable transgene expression and low vector-specific cellular immune responses, initial studies on preclinical validation of recombinant (r) AAV have focused on its utility to correct monogenic defects. ${ }^{4-6}$ However, recent reports have indicated the potential of $\mathrm{rAAV}$ for nongenetic disorders including infectious diseases and cancer. ${ }^{7-10}$ Potential advantages of AAV as vector for genetic immunotherapy are sustained transgene expression and absence of vector

Correspondence: Dr S Ponnazhagan, Department of Pathology, University of Alabama at Birmingham, 513 Lyons-Harrison Research Building, 701, 19th Street South, Birmingham, AL 352940007, USA.

E-mail: sponnazh@path.uab.edu

Received 6 March 2005; revised 17 May 2005; accepted 22 June 2005; published online 1 September 2005 genes encoding viral structural proteins thereby minimizing antigenic competition. Most of the current understanding of the potential for $\mathrm{AAV}$ in gene therapy is based upon studies with AAV serotype 2-based vectors. One type of target cells refractory for AAV serotype 2 transduction, however, is dendritic cells (DC).

DC play a key role in initiating and controlling immune responses. In addition to being the most potent antigen-presenting cells (APC), DC determine the type and magnitude of immune responses and provide a link between innate and acquired immunity. ${ }^{11}$ Genetic manipulation of DC offers greater potential for the development of immune-regulatory strategies for purposes ranging from active immunization to tolerance induction. The capacity of DC modified to express antigens, cytokines or $\mathrm{T}$-cell costimulatory molecules to induce T-helper 1 and 2 (Th1/Th2)-biased immune responses has provoked considerable interest in utilizing these cells for therapeutic applications. Our previous studies of human peripheral blood monocyte-derived DC indicated 
varying efficiency of AAV2 transduction. ${ }^{12}$ Other preclinical studies of the application of rAAV to DC-based immunotherapies have also been limited by poor transduction efficiency of DC by serotype 2 vectors. ${ }^{13-15}$

Alternate serotype vectors with different host cell receptor specificity have increased the repertoire of AAV available for gene therapy applications. ${ }^{16-19}$ With the goal of developing DC-based preclinical ex vivo immunotherapy approaches, we tested the ability of rAAV encapsidated in serotype 6 capsids to transduce murine bone marrow-derived DC during different stages of DC differentiation and maturation in vitro. Conventionally, rAAV genome is packaged as a single-stranded molecule. A rate-limiting step for the expression of transgene is the synthesis of a transcriptionally active doublestranded DNA, which requires host-cell factors. rAAV containing self-complementary (sc), that is, doublestranded genome, which is packaged as a doublestranded structure, bypasses the rate-limiting step of second-strand synthesis. ${ }^{20,21}$ Our results indicate that efficient transduction of murine DC with the human tumor antigen, carcinoembryonic antigen (CEA), could be accomplished with sc rAAV6. Furthermore, activation of cultured DC with immunostimulatory CpG oligodeoxynucleotides (ODN) and agonist CD40 antibody greatly enhanced transgene expression. Adoptive transfer of these DC transduced and activated ex vivo stimulated humoral and cellular immune responses in vivo and confirmed the potential of SC rAAV6 vectors for immunotherapy applications.

\section{Results}

\section{Repeated exposure of DC to sc rAAV6 improves transduction efficiency and does not alter DC phenotype}

To determine if mouse bone marrow-derived DC can be transduced with alternate AAV serotype capsids, we first established the transduction efficiency of rAAV expressing beta-galactosidase ( $\beta$-Gal) encapsidated in serotype $1,2,3,4,5$ and 6 capsids. Mouse bone marrow-derived cells were transduced with rAAV- $\beta$-Gal on days 2 and 4 of culture with IL-4 and GM-CSF. Results indicated that transduction efficiency of the rAAV6 serotype vector was significantly higher than that of rAAV2, based on transgene expression (Figure 1). $\beta$-Gal expression in DC transduced with AAV serotypes 3, 4 and 5 was insignificant. Transduction efficiency of AAV serotype 1 was higher than AAV2 but lesser than AAV6 (data not shown). Based on these results, we constructed and validated rAAV containing human CEA cDNA either as single-stranded genome (ss) or as self-complementary double-stranded genome $(s c)$ packaged in serotype 6 AAV capsid (Figure 2). For generating $s c$ AAV with CEA, we cloned a short version of CEA, CEA70, derived from the MC38-CEA-2 cell line, which contains a spontaneously arising deletion within the homologous internal repeat domains of CEA. ${ }^{22}$

In the next set of experiments, we sought to determine if repeated transduction of mouse DC cultures by $s c$ rAAV6-CEA on days 2, 4 and 7 of in vitro culture would improve transduction efficiency. Higher levels of transduction were achieved with sc rAAV6 when compared to ss rAAV6 (Figure 3). Further, transduction efficiency was significantly improved when rAAV6-CEA was transduced sequentially on days 2, 4 and 7 of DC culture. Multiple infections with rAAV6-CEA did not alter DC viability. The untransduced and Sc rAAV6-transduced DC cultures were also analyzed by flow cytometry to determine if repeated transduction of mouse DC cultures by rAAV6-CEA would alter DC development. As shown in Figure 4, there was no significant difference in the expression of the marker CD11c or the adhesion molecule CD54, or the costimulatory molecules CD80
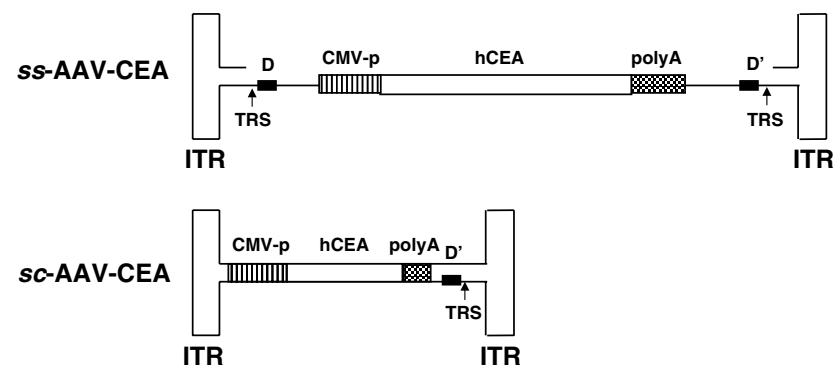

Figure 2 Organization of rAAV6 encoding human CEA either as single-stranded $(s s)$ or self-complementary $(s c)$ genome. The $s c$ rAAV6-CEA was generated by removing the $5^{\prime}$ TRS and ' $\mathrm{D}$ ' sequences whereas the conventional ss AAV6-CEA was generated with both TRS and ' $\mathrm{D}$ ' sequences.
Mock

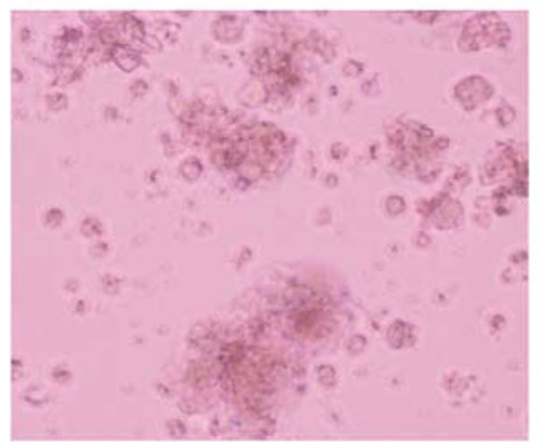

AAV2- $\beta$ Gal

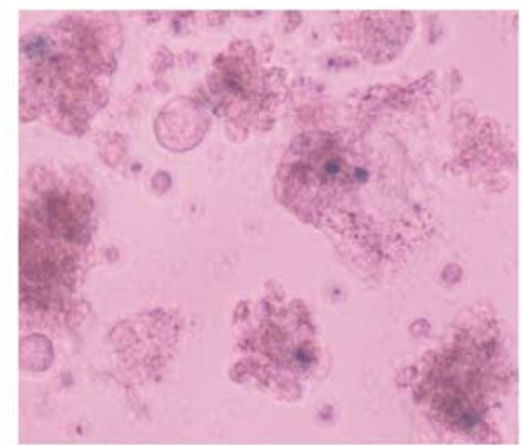

AAV6- $\beta$ Gal

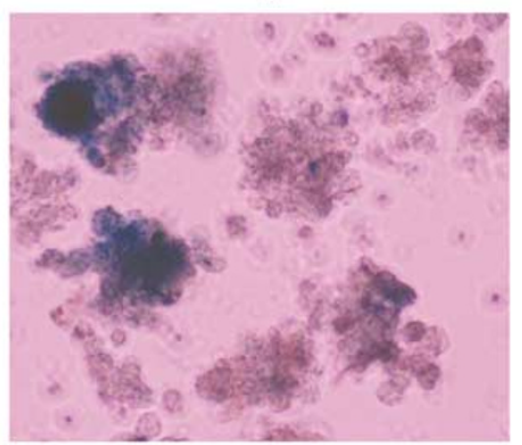

Figure 1 Transduction of mouse bone marrow-derived DC with rAAV- $\beta$-Gal encapsidated in serotype 2 and 6 capsids. Mouse DC precursors were transduced with rAAV at an MOI of 1000 on days 2 and 4 of culture. Transgene expression was determined on day 8 by the addition of $150 \mu \mathrm{g} / \mathrm{ml} \mathrm{X-gal} \mathrm{directly} \mathrm{into} \mathrm{the} \mathrm{culture} \mathrm{medium.}$ 

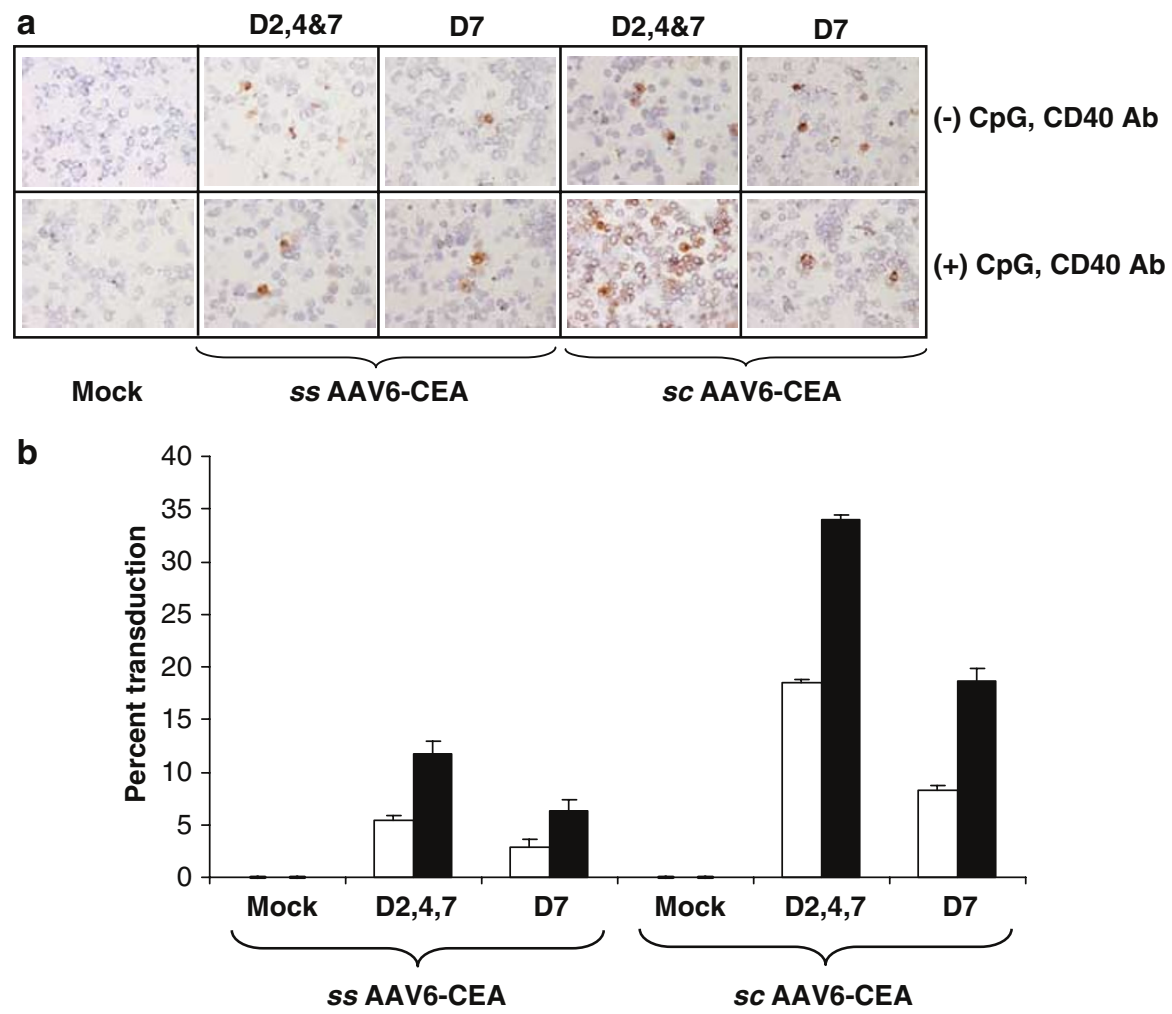

Figure 3 Immunocytochemistry analysis of mouse DC transduced with rAAV6-CEA. Mouse bone marrow-derived DC precursors were either mock-transduced or transduced with $100 \mathrm{MOI}$ of $s s$ or $s c$ rAAV6-CEA either on days 2, 4 and 7 (D2,4\&7) or only on day 7 (D7) of culture in the presence of IL-4 and GM-CSF. Replicate cultures were activated on day 8 with $1 \mu \mathrm{M}$ CpG ODN (CpG) and $1 \mu \mathrm{g} / \mathrm{ml}$ mouse CD40 antibody $(\mathrm{CD} 40 \mathrm{Ab})$. The cells were harvested on day 9 and fixed on microscope slides by cytospin and stained with anti-CEA antibody COL1. The cells were minimally counterstained with hematoxylin before mounting and evaluation by light microscopy (magnification $\times 20$ ). (a) CEA staining in the absence (top panel) or presence (lower panel) of activation with CpG ODN and CD40 antibody. (b) Percentage of CEA-positive DC in the absence ( $\square$ ) or presence of activation with CpG ODN and CD40 antibody

and CD86, among the untransduced and transduced DC cultures.

As an additional measure of $s c$ rAAV6 transduction of mouse DC, we performed real-time PCR analysis with total DNA of transduced cells to quantify the vector genome using AAV6-CEA-specific primers. Vector copy was normalized to the copy number of cellular GAPDH gene. Results shown in Figure 5 indicate approximately 464 copies of rAAV6 per DC on day 9 of culture, transduced three times with $s c$ rAAV6-CEA earlier. It is possible that transduction of rAAV6 may not have occurred in all DC, and also that not all copies of vector genome may be transcriptionally active. Nonetheless, the presence of vector sequences in mouse DC clearly indicated that the cells are transducible by AAV serotype 6 capsids. The copy number of vector genome between $s c$ and ss rAAV transduction did not show significant variation (data not shown).

\section{CEA transgene expression in DC following Sc rAAV6 transduction increases upon maturation with $C p G$ ODN and CD40 agonist antibody}

DC must be activated/matured for optimal antigen presentation. Activation of DC, which is accompanied by upregulation of several cell surface molecules, can be achieved by various stimuli. Activation of DC through the CD40 pathway or toll-like receptor (TLR) pathway leads to the upregulation of intracellular factors that play a key role in transcriptional activation including the NF$\kappa \mathrm{B}$ and $\mathrm{AP}-1$. Therefore, we determined whether induction of DC maturation by CPG ODN and CD40 antibody following multiple transduction with rAAV6-CEA would enhance transgene expression. Mouse DC were grown in culture with IL-4 and GM-CSF for 8 days and transduced with $s S$ or $s c$ rAAV6-CEA on days 2, 4 and 7, or only on day 7. Maturation was induced with $1 \mu \mathrm{g} / \mathrm{ml} \mathrm{CpG} \mathrm{ODN}$ and $1 \mu \mathrm{g} / \mathrm{ml}$ anti-mouse CD40 antibody. Replicate cultures were maintained without the addition of $\mathrm{CpG}$ ODN and CD40 antibody. DC were harvested $24 \mathrm{~h}$ later and stained with the human CEA antibody COL-1. Results (Figure 3) show that CEA protein expression was dramatically increased following CD40 antibody plus CpG ODN treatment in the DC transduced multiple times with sc rAAV6. Although there was an observable increase in CEA-positive cells when the cells were transduced only once (day 7 of culture) followed by activation with CD40 antibody and CpG ODN, it was significantly less compared to that observed in DC transduced multiple times. CEA expression in ss AAVCEA-transduced cells was also significantly less compared to $s c$ rAAV-CEA transduction irrespective of whether DC were transduced once or multiple times.

Affymetrics gene chip analysis was performed to investigate changes in expression of genes pertinent to DC activation and maturation as well as transactivation of the CMV promoter following DC activation with CpG ODN and CD40 antibody. RNA was isolated from rAAV- 

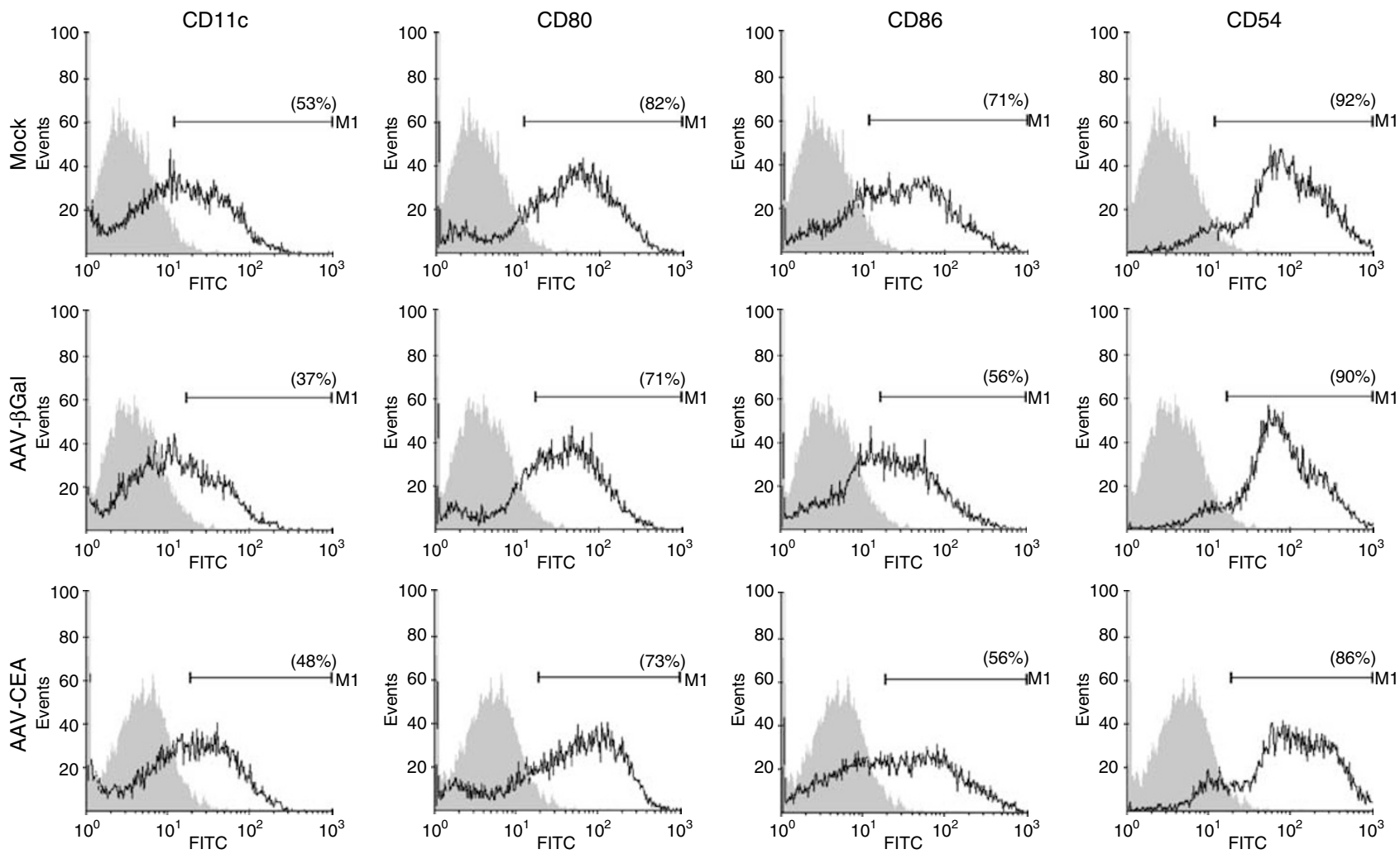

Figure 4 Expression of DC markers in mock-, rAAV6- $\beta$-Gal- and $s c$ rAAV6-CEA-transduced mouse DC. Mouse bone marrow-derived DC precursors were either mock-transduced or transduced with 1000 MOI of rAAV6 encoding $\beta$-Gal or sc rAAV6 expressing CEA on days 2, 4 and 7 of culture in the presence of IL-4 and GM-CSF. Cells were harvested on day 9 and analyzed by flow cytometry using FITC-labeled CD11c, CD54, CD80 and CD86 antibodies. Isotype control for each group is indicated in gray.

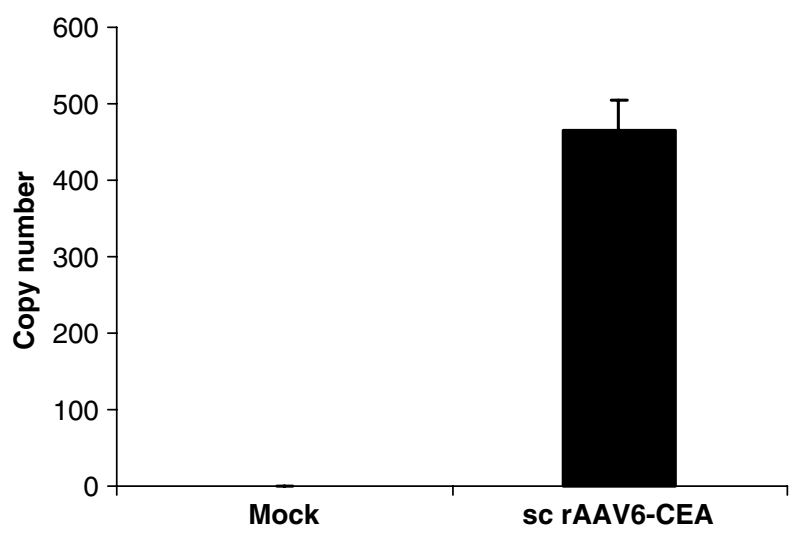

Figure 5 Semiquantitative real-time PCR analysis of sc rAAV6CEA copy number in transduced mouse DC. Real-time PCR was performed with $500 \mathrm{ng}$ of total DNA from mock- or sc rAAV6-CEAtransduced DC using primer pairs to amplify both vector-specific and mouse GAPDH gene-specific sequences. Values indicate the copy number of vector genome per cell, normalized to the copy number of GAPDH amplification from the same sample.

CEA-transduced mouse DC, either activated with CD40 antibody plus CpG ODN or without activation. Several genes in DC that were transduced with sc rAAV6-CEA and activated with CpG ODN and CD40 antibody manifested a minimum four-fold difference compared to DC that were transduced with $S C$ rAAV6-CEA but not activated with CpG ODN and CD40 antibody. Of interest, there was upregulation of cytokine genes and genes involved in immune response (Table 1) and genes involved in transcription regulation, cell proliferation and cell cycle control (Table 2). Downregulation of genes involved in cytokine signaling, inhibition of transcription regulation and cell proliferation was also observed (Table 3). In particular, there was nearly 70-fold downregulation of the inhibitor of DNA binding 3 (Idb3) transcript following DC activation. Idb3 proteins are known to interfere with the binding of transcriptional factors. ${ }^{23}$

\section{Immunization with sc rAAV6-CEA-transduced DC elicits transgene-specific immune response}

As a measure of immunostimulatory potential of $s C$ rAAV6-CEA-transduced DC in vivo, C57BL/6 mice were vaccinated twice with unmodified, rAAV6- $\beta$-Gal- (nonspecific vector control) or rAAV6-CEA-transduced and CPG ODN plus CD40 antibody activated DC and studied for CEA-specific antibody responses. ELISA was performed to detect IgG antibodies against CEA. In addition, isotype analysis of IgG1, IgG2a, IgG2b and IgG3 was also carried out for CEA antibodies. As a positive control, serum samples were obtained from C57BL/6 mice immunized intramuscularly with a plasmid vector encoding human CEA, known to elicit a strong humoral response. ${ }^{22,24}$ Results are shown in Figure 6. Immunization with rAAV6-CEA-transduced DC elicited a significant humoral response to CEA that was comparable to that following immunization with plasmid DNA. There was no CEA-specific IgG antibody detected in naïve mice or mice immunized with control 
Table 1 Cytokine and immune response related genes upregulated in sc rAAV-CEA-transduced mouse DC following CpG ODN and CD40 $\mathrm{Ab}$ treatment ${ }^{\mathrm{a}}$

\begin{tabular}{|c|c|c|}
\hline Gene symbol & Gene title & Fold upregulation \\
\hline Ptgs2 & Prostaglandin-endoperoxide synthase 2 & 207.94 \\
\hline $\mathrm{Il} 12 \mathrm{~b}$ & Interleukin $12 \mathrm{~b}$ & 30.70 \\
\hline Cxcl1 & Chemokine (C-X-C motif) ligand 1 & 21.41 \\
\hline Tnfsf7 & Tumor necrosis factor (ligand) superfamily, member 7 & 10.63 \\
\hline IL-6 & Interleukin 6 & 9.25 \\
\hline Cxcl5 & Chemokine (C-X-C motif) ligand 5 & 9.19 \\
\hline Нc & Hemolytic complement & 8.57 \\
\hline $\mathrm{Cxcl} 2$ & Chemokine (C-X-C motif) ligand 2 & 8.34 \\
\hline Ifit1 & Interferon-induced protein with tetratricopeptide repeats 1 & 6.45 \\
\hline Tnfrsf5 & Tumor necrosis factor receptor superfamily, member 5 & 6.41 \\
\hline Il23a & Interleukin 23, alpha subunit p19 & 6.19 \\
\hline G1p2 & Interferon, alpha-inducible protein & 5.70 \\
\hline Ifi16 & Interferon, gamma-inducible protein 16 & 5.50 \\
\hline Ly6a & Lymphocyte antigen 6 complex, locus A & 5.24 \\
\hline Il15 & Interleukin 15 & 4.82 \\
\hline Oasl2 & $2^{\prime}-5^{\prime}$ oligoadenylate synthetase-like 2 & 4.69 \\
\hline H2-T24 & Histocompatibility 2 , T region locus 24 & 4.63 \\
\hline Illb & Interleukin-1 beta & 4.47 \\
\hline Tnfsf9 & Tumor necrosis factor (ligand) superfamily, member 9 & 4.41 \\
\hline Ly6i & Lymphocyte antigen 6 complex, locus I & 4.26 \\
\hline Ifit2 & Interferon-induced protein with tetratricopeptide repeats 2 & 4.20 \\
\hline Igsf9 & Immunoglobulin superfamily, member 9 & 4.20 \\
\hline Icsbp1 & Interferon consensus sequence binding protein 1 & 4.08 \\
\hline Oas3 & $2^{\prime}-5^{\prime}$ oligoadenylate synthetase 3 & 4.06 \\
\hline Ifi205 & Interferon activated gene 205 & 4.00 \\
\hline
\end{tabular}

${ }^{a}$ Genes listed indicated a minimum of four-fold difference in the expression compared to DC that were transduced with rAAV-CEA but not activated with CpG ODN and CD40 antibody.

Table 2 Transcription regulation, cell proliferation and cell cyclerelated genes upregulated in sc rAAV-CEA-transduced mouse DC following CpG ODN and CD40 Ab treatment ${ }^{\mathrm{a}}$

\begin{tabular}{llc}
\hline $\begin{array}{l}\text { Gene } \\
\text { symbol }\end{array}$ & Gene title & $\begin{array}{c}\text { Fold } \\
\text { upregulation }\end{array}$ \\
\hline Rrm2b & $\begin{array}{l}\text { Ribonucleotide reductase M2 B (TP53 } \\
\text { inducible) }\end{array}$ & 20.39 \\
Nr4a2 & $\begin{array}{l}\text { Nuclear receptor subfamily 4, group A, } \\
\text { member 2 }\end{array}$ & 19.03 \\
Arnt2 & Aryl hydrocarbon receptor nuclear & 16.80 \\
Klf1 & Kranslocator 2 & 11.55 \\
Mbd311 & Methyl-CpG binding domain protein 3-like 1 & 9.65 \\
Zfp1 & Zinc finger protein 1 & 8.17 \\
Hspa1b & Heat shock protein 1B & 5.94 \\
Map3k8 & Mitogen activated protein kinase kinase & 5.03 \\
kag1 & Jagge 8 & 4.76 \\
Icsbp1 & Interferon consensus sequence binding & 4.56 \\
Irf7 & Interfein 1 & 4.53 \\
Prss11 & Serine Protease 11 (Igf binding) & 4.50 \\
Prss11 & Serine Protease 11 (Igf binding) & 4.50 \\
Smug1 & Single-strand selective monofunctional & 4.47 \\
Lck & uracil DNA glycosylase & \\
Ikbkb & Inhibitoryte protein tyrosine kinase & 4.35 \\
\hline
\end{tabular}

${ }^{a}$ Genes listed indicated a minimum of four-fold difference in the expression compared to DC that were transduced with rAAV-CEA but not activated with CpG ODN and CD40 antibody.

DC. Antibody isotype studies indicated that $\operatorname{IgG} 2 b$ was the predominant CEA-reactive antibody in sera from DC-immunized mice with a lower level of IgG1 antibody detected (Figure 6b).
Table 3 Genes downregulated in $s c$ rAAV-CEA-transduced mouse $\mathrm{DC}$ following CpG ODN and CD40 Ab treatment ${ }^{a}$

\begin{tabular}{llc}
\hline $\begin{array}{l}\text { Gene } \\
\text { symbol }\end{array}$ & Gene title & $\begin{array}{c}\text { Fold } \\
\text { downregulation }\end{array}$ \\
\hline Idb3 & Inhibitor of DNA binding 3 & 69.07 \\
Paxip1 & PAX interacting protein 1 & 7.84 \\
EGF-BP & Epidermal growth factor binding protein & 7.46 \\
Il1r2 & Interleukin1 receptor type II & 4.23 \\
\hline
\end{tabular}

aGenes listed indicated a minimum of four-fold difference in the expression compared to DC that were transduced with rAAV-CEA but not activated with CpG ODN and CD40 antibody.

Evidence for CEA-specific cellular immune response was indicated by the induction of Th1-associated cellular response (Figure 7). Production of significant CEA-specific IFN- $\gamma$ by splenocyte cultures from mice immunized with DC, transduced with rAAV-CEA and activated with CpG ODN and CD40 antibody strongly suggests the capacity of rAAV6-CEA as cancer vaccine.

\section{Immunization with sc rAAV6-CEA-transduced DC elicits antibody with neutralizing effects on AAV6 but not AAV2}

We also investigated the elicitation of AAV capsidspecific antibodies following immunization with $s C$ rAAV-CEA-transduced DC, and compared this to capsid antibody titers in mice receiving direct intramuscular injections of rAAV6-CEA. As shown in Figure 8, sc rAAVCEA-transduced DC immunization appeared to elicit a more rapid and robust immune response to AAV6 capsids as compared to direct injection of rAAV6-CEA into mouse muscles. 
To determine the neutralizing effects of anti-AAV6 capsid antibody and crossreactivity with serotype 1, 2, 3, 4 and 5 capsids, sera from control and sc rAAV6-CEAtransduced DC vaccinated mice were incubated with rAAV- $\beta-$ Gal in each of the serotypes and tested for trans-
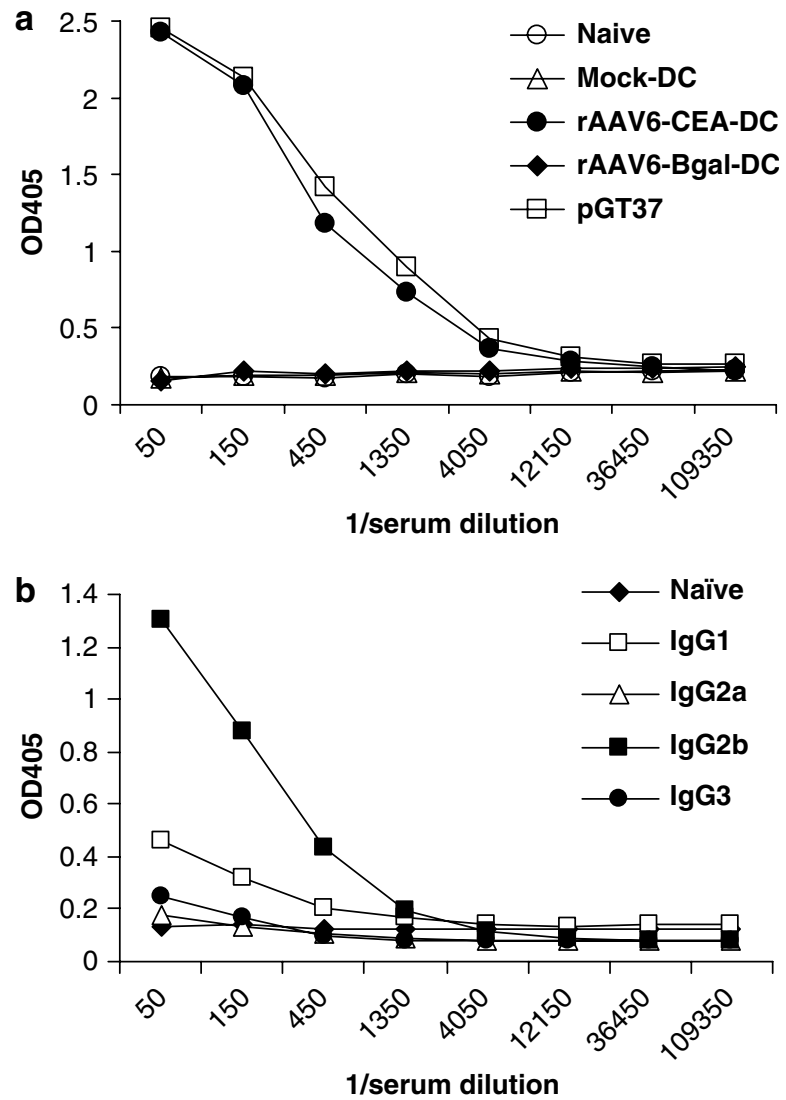

Figure 6 Serum antibody titers for CEA elicited by vaccination with rAAV6-CEA-transduced mouse DC in C57BL/6 mice. Cohorts of mice were vaccinated twice with $100000 \mathrm{DC}$, which were mocktransduced or transduced with rAAV6-CEA or $\beta$-Gal, after activation with $\mathrm{CpG}$ ODN and CD40 antibody. As a positive control, serum samples from mice immunized with a plasmid vector encoding human CEA were included. Serum samples were obtained 15 days after the second vaccination. (a) Total IgG antibody levels against CEA as determined by ELISA. (b) Isotype analysis was performed with indicated IgG secondary antibodies in serum samples of sc rAAV6-CEA-transduced DC vaccinated mice.

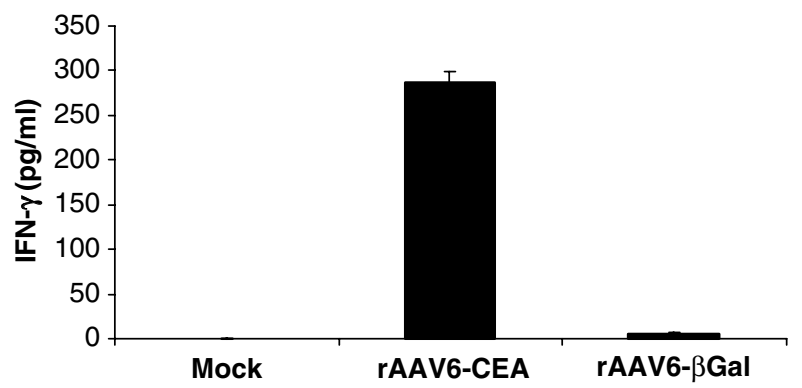

Figure 7 IFN- $\gamma$ production as a measure of Th1 response following vaccination with rAAV6-CEA-transduced and activated DC. Spleen cells obtained from C57BL/6 mice, following vaccination of mocktransduced or rAAV-transduced and activated DC, were cultured in the presence of $50 \mu \mathrm{g} / \mathrm{ml} \mathrm{CEA} \mathrm{for} 3$ days. Supernatants from the respective cultures were used to determine IFN $-\gamma$ by ELISA. duction efficiency in human embryonic kidney (HEK) 293 cells. Results shown in Figure 9 indicate that the greatest neutralizing activity was observed for rAAV6 transduction, with approximately $75 \%$ inhibition by $1 / 10$ diluted serum. There was also significant inhibitory activity against AAV1, although it was observed only with highest concentration of serum. However, there was no inhibitory activity observed for serotype 2, 3, 4 and 5 transductions.

\section{Discussion}

The potential of rAAV vectors for human gene therapy is gaining more attention as evident from the initiation of multiple clinical trials for monogenic diseases. ${ }^{4-6}$ In addition, potential applications of AAV as a vector for immunotherapy of infectious diseases and cancer are being developed. ${ }^{2,7,8,10,12}$ Although most of the preclinical studies and clinical trials so far have utilized serotype 2 AAV vectors, recent studies suggest that alternate serotype vectors with different host cell receptor specificity could have better utility for gene transfer to rAAV2 refractory target cells. ${ }^{16-19}$ One of the cell types that shows poor transduction efficiency for rAAV2 is DC, mouse DC in particular. ${ }^{14,15}$

DC are sentinels of immune system and are the pivotal antigen-presenting cells for regulating humoral and cellular immune responses. ${ }^{25,26}$ Promising results obtained in preclinical studies by ex vivo modification of DC with protein/peptide pulsing and viral vector-mediated gene transfer clearly demonstrate the potential utility of these cells in immunotherapy. ${ }^{13,27,28}$ Studies with other viral vectors including adenovirus, retrovirus and vaccinia virus have shown transduction of DC and their immunostimulatory potential in vivo, but a major concern is the generation of significant cellular immune response to vector proteins included as part of the transgene cassette, which may compete with the immune response directed against the transgenic protein. ${ }^{29,30}$ rAAV may overcome these limitations due to the absence of vector coding sequences and stable transgene expres-

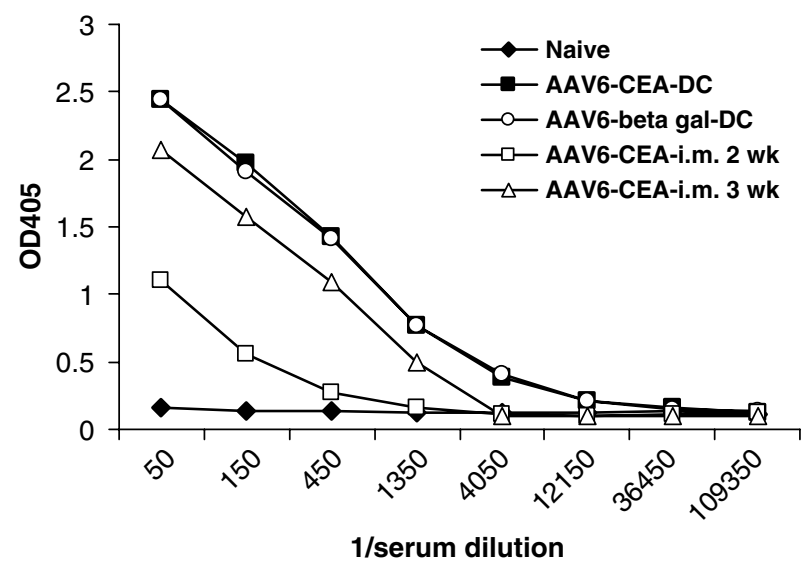

Figure 8 Serum antibody titers for AAV6 capsid elicited by vaccination with rAAV6-CEA-transduced and CpG ODN plus CD40 antibody activated mouse DC in C57BL/6 mice. Serum samples obtained from mock-transduced or rAAV6-CEA- or $\beta$-Galtransduced DC vaccinated mice were pooled and used for the determination of IgG antibody levels to AAV6 capsid. The antibody titers were compared to AAV6 antibody levels in serum samples of mice immunized intramuscularly with $s c$ rAAV6-CEA. 
AAV-1
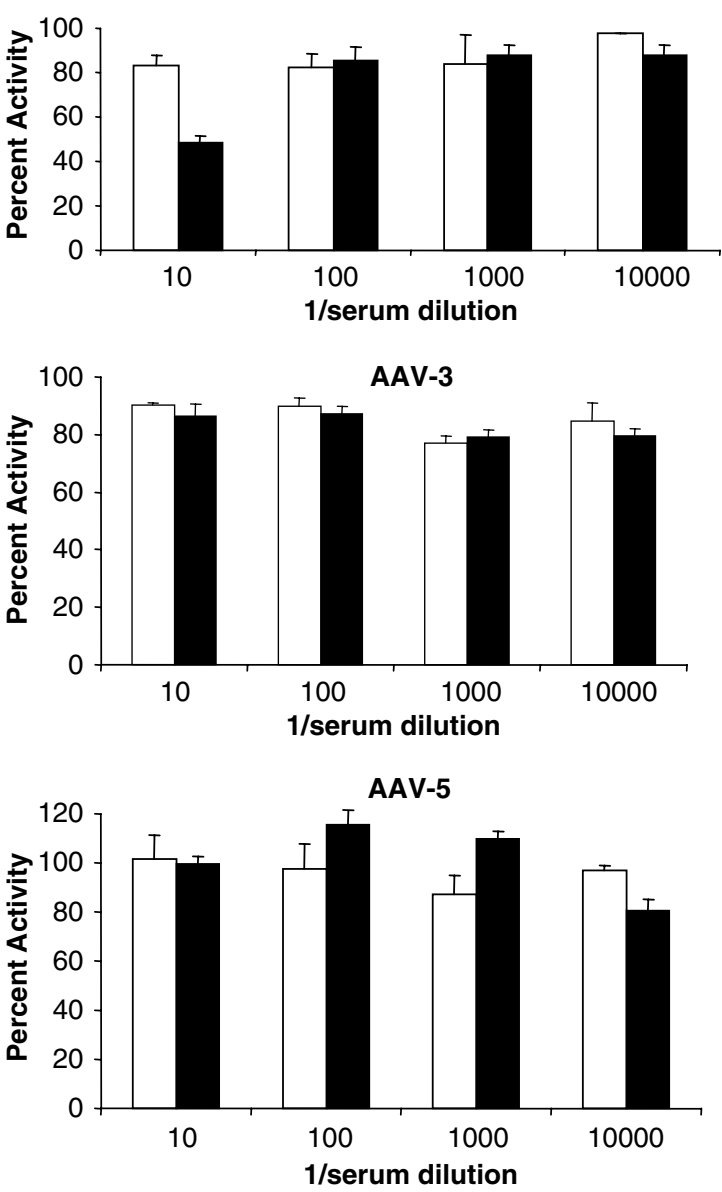

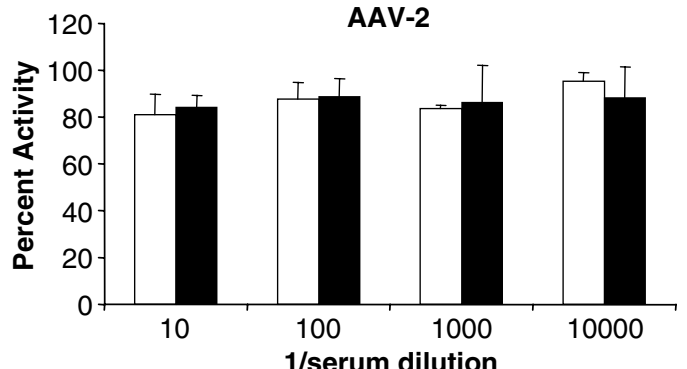

AAV-4

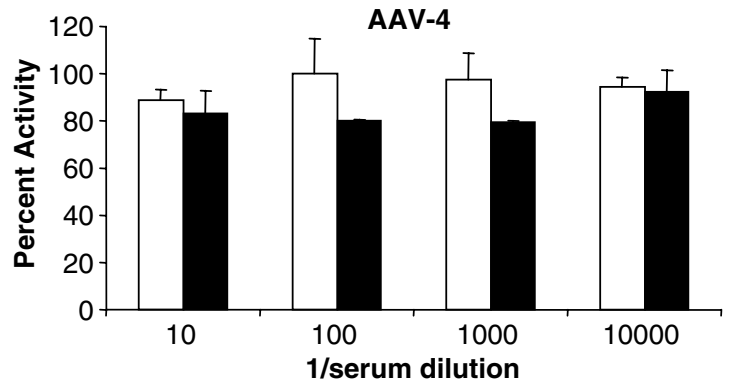

AAV-6

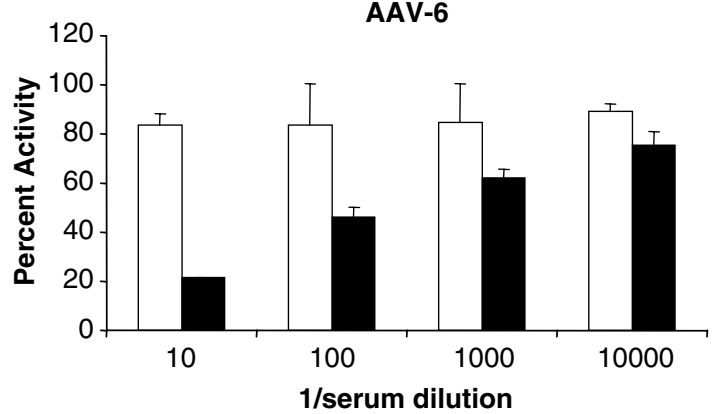

Figure 9 Assay for neutralizing antibody to AAV in serum of C57BL/6 mice vaccinated with rAAV6-CEA-transduced and activated DC. Serum samples obtained from C57BL/ 6 mice 15 days after the second vaccination of DC transduced with rAAV6-CEA on days 2, 4 and 7 and activated with CpG ODN plus CD40 antibody $(\boldsymbol{\square})$ or serum samples from naïve ( $\square$ ) mice were pooled and diluted with PBS. Then, 10-fold dilutions of the pooled sera were incubated with $5 \times 10^{8}$ particles of rAAV- $\beta$-Gal encapsidated in serotype $1,2,3,4,5$ and 6 capsids at $37^{\circ} \mathrm{C}$ following which the virus was used for infection of 293 cells in 24-well plates. After $48 \mathrm{~h}$, the cells were lysed and $\beta$-Gal activity was determined and expressed as percentage activity compared to $\beta$-Gal activity from respective AAV serotype transduction in 293 cells without preincubation.

sion. However, poor transduction of DC greatly impairs the utility of $\mathrm{rAAV}$ for immunotherapy.

In order to determine the potential of alternate AAV serotype vectors in the transduction of murine bone marrow-derived DC, we tested serotypes $1,2,3,4,5$ and 6 and identified that rAAV vectors encapsidated in serotype 6 capsids show improved transduction of these cells. Based on amino-acid homology among AAV capsids, it is believed that AAV serotype 6 is a product of recombination between serotypes 1 and $2 .{ }^{31}$ Interestingly, transduction efficiency of rAAV1 in DC was relatively lesser than that of rAAV6 although higher than rAAV2. The capsid protein of AAV6 and AAV1 serotypes differs only by 6 amino acids. Thus, higher transduction observed with rAAV6 may partially be due to differences in intracellular trafficking during DC differentiation and maturation. High-efficiency transduction of rAAV6 serotype vectors has been recently reported in preclinical mouse models of cystic fibrosis and muscular dystrophy, ${ }^{32,33}$ which is quite distinct from transduction efficiency of serotype 2 vectors. The putative receptor for AAV serotype 6 has not yet been identified. Thus, it remains possible that in addition to an abundance of putative receptor/coreceptor that facilitates enhanced infection by serotype 6 capsids, intracellular events including nuclear transport and uncoating might be mediated by cellular factors other than what has been reported so far for serotype 2 vectors. ${ }^{34-36}$ Since most of the studies to date with $\mathrm{rAAV}$, including our own, utilized AAV2 inverted terminal repeats (ITR) in the vector genome, the observed difference in transduction efficiency between serotype 2 and 6 vectors may not be due to defects in second-strand synthesis or other molecular reorganization events including annealing of 'plus' and 'minus' strands, and DNA concatamerization.

The results of the present study clearly demonstrate that it is possible to achieve significant transduction of mouse bone marrow-derived DC with AAV6, which were refractory to AAV2 transduction. The potential of rAAV6 with genomic organization as a self-complementary structure is clearly evident in the transduction of mouse DC. Recently, it has been demonstrated that when rAAV is packaged using half of the wild-type genomic length, the DNA can be encapsidated as a self-complementary double-strand molecule. ${ }^{20,21}$ Vector genome packaged this way is believed to bypass the requirement 
for host-dependent leading strand synthesis and thus effect earlier transgene expression as compared to ss vectors. ${ }^{20,21}$ Although gene-modified ex vivo DC therapy is a very promising approach, unlike other ex vivo approaches involving stem cell transduction, DC are short-lived both in culture and upon syngeneic/adoptive transfer in vivo. Thus, it is crucial to achieve optimal antigen expression as soon as possible following vector transduction.

DC must be activated/matured to optimally present antigens. Several molecular activators of DC have been identified. Agonistic anti-CD40 antibody and ligands of TLRs such as ODN containing CpG motifs (TLR9 ligand) are particularly effective and result in DC with potent immunostimulatory activity. ${ }^{11}$ We found that activation of DC with anti-CD40 antibody and CpG ODN enhanced the expression on the rAAV encoded transgene. Upregulation of IL-1, IL-6, IL-15, IL-23, TNF receptor family genes, prostaglandin synthase and chemokine ligand 1 (Cxcl1) may reflect activation of the DC upon treatment with CpG ODN plus anti-CD40 antibody. Cytokines such as IL-15 play a central role in DC immunostimulatory activities. ${ }^{37}$ Upregulation of transcriptional factors including the kruppel-like factor (Klf1), zinc-finger protein 1 (Zfp1), ribonucleotide reductase (Rrm2b) and interferon consensus sequence binding protein (Icsbp1) may be related to the effect of DC activation on augmentation of the vector-encoded transgene (as shown in Figure 3). Interestingly, activation with CpG ODN plus CD40 antibody in our study was accompanied by a nearly 70-fold downregulation of the Idb3 transcript. The Idb3 protein is known to play an important role in the control of cell differentiation by interfering with DNA binding of transcription factors. ${ }^{23}$ Thus, the dramatic difference in transgene expression following activation of DC by CpG ODN plus CD40 antibody could have partly been due to downregulation of Idb3 in addition to upregulation and nuclear localization of transcription factors that facilitated efficient transgene expression.

DC transduced with SC rAAV6-CEA and activated with CpG plus CD40 antibody ex vivo were active in vivo. Mice immunized with these DC developed both anti-CEA antibody and CEA-specific Th1-associated cellular immune response. The induction of CEA-specific IgG2b antibody and production of IFN- $\gamma$ in splenocyte cultures are suggestive of a Th1 type immune response, which is considered essential for antitumor immunity. Although AAV6 is believed to be a hybrid serotype of AAV1 and AAV2, ${ }^{31}$ transduction efficiency of AAV1 and AAV6 has been reported to be much more efficient than AAV2. ${ }^{16-18,31,33}$ The results of our neutralizing antibody assays indicate the absence of significant crossreactivity of AAV6 antibodies with serotype 2, 3, 4 and 5 capsids, and measurable crossneutralization of serotype 1 capsid. Thus, future cancer gene therapy approaches may use combinations of AAV serotypes that circumvent crossreactive capsid immunity, either as repeated unimodal or multimodal regimens. Cancer gene therapy approaches such as antiangiogenic therapy, which mandate systemically stable levels of therapeutic factors, may particularly benefit by such combination. Taken together, strategies to enhance transduction and transgene expression of mouse DC with AAV6-based recombinant vector will lead to preclinical validation of ex vivo DC-based vaccination approaches using AAV and may be optimally translated to human clinical trials in future.

\section{Materials and methods}

\section{Cell lines and reagents}

The HEK293 cells were obtained from American Type Culture Collection and maintained as described previously. ${ }^{12,38}$ Plasmid pSub201, containing the wild-type (wt) AAV2 genome, was a kind gift of Dr Jude Samulski (University of North Carolina, Chapel Hill, NC, USA), and a recombinant helper plasmid containing AAV6 capsid gene was a kind gift of Dr David Russell (University of Washington, Seattle, WA, USA). The construction of recombinant AAV plasmids containing either the $\beta$-Gal or the full-length human CEA gene for packaging as a single-stranded DNA has been described. ${ }^{10}$ A recombinant AAV plasmid containing CEA for packaging as a double-stranded self-complementary genome was constructed by subcloning a short $(70 \mathrm{kDa})$ version of human $\mathrm{CEA}^{22}$ in the AAV plasmid pLY4 (kind gift of Dr Arun Srivastava, University of Florida, Gainesville, FL, USA) as described below. Human CEA protein was purchased from either Fitzgerald Industries International Inc. (Concord, MA, USA) or Aspen Bio Inc. (Littleton, CO, USA). Mouse monoclonal antibody COL-1 to human CEA was purchased from NeoMarkers (Freemont, CA, USA) and anti-mouse CD40 antibody was purchased from BD Biosciences Pharmingen (San Diego, CA, USA). FITC-conjugated antibodies for mouse CD11c, CD54, CD80 and CD86 were purchased from BD Pharmingen. Alkaline phosphatase (AP)-conjugated goat anti-mouse IgG and IgG subtypes (IgG1, IgG2a, IgG2b and IgG3) secondary antibodies were purchased from Southern Biotechnology Assoc. (Birmingham, AL, USA), and AP substrate was from Sigma Chemical Co. (St Louis, MO, USA). CpG ODN were purchased from Sigma.

\section{Construction, packaging and purification of rAAV in serotype 6 capsids}

The construction of rAAV containing human CEA as single-stranded genome (ss) has been described. ${ }^{10} \mathrm{~A}$ recombinant AAV plasmid containing the same transgene for packaging as self-complementary structure (sc) was constructed using the plasmid pLY-4 in which the ' $\mathrm{D}$ ' and terminal resolution site (TRS) sequences at the $5^{\prime}$ end of the genome were deleted. Packaging and purification of rAAV were carried out by helper virusfree transient transfection. Vented-cap roller bottles $\left(850 \mathrm{~cm}^{2}\right.$; Corning, New York, NY, USA) were seeded with $1.8 \times 10^{7}$ HEK293 cells in $140 \mathrm{ml}$ Dulbecco's modified Eagle's medium (DMEM) containing 10\% fetal calf serum (FCS). The cultures were incubated at $37^{\circ} \mathrm{C}$ with $5 \% \mathrm{CO}_{2}$ and rotated at 0.2 rounds per min for 3 days before transfection. For each roller bottle, $10 \mathrm{ml}$ of $300 \mathrm{mM} \mathrm{CaCl}_{2}$ containing $100 \mu \mathrm{g}$ each of the pAAV-CEA vector plasmid and the two helper plasmids (pladeno5 and pHLP6) was rapidly mixed with $10 \mathrm{ml}$ of $2 \times \mathrm{HBS}$ (HEPES-buffered saline; $50 \mathrm{mM}$ HEPES (N-2-hydroxyethylpiperazine- $N^{\prime}$-2-ethanesulfonic acid), $280 \mathrm{mM}$ $\mathrm{NaCl}, 1.5 \mathrm{mM} \mathrm{NaH}_{2} \mathrm{PO}_{4}, \mathrm{pH} 7.1$ ) and added to the roller bottle within $10 \mathrm{~min}$. After $6 \mathrm{~h}$ transfection, the medium was replaced with $100 \mathrm{ml}$ of serum-free DMEM and cultures were incubated for $72 \mathrm{~h}$. Vector-containing cells were dislodged from the sides of the roller bottles by gentle swirling and pelleted by centrifugation at $1000 \mathrm{~g}$ 
for $15 \mathrm{~min}$ at $4^{\circ} \mathrm{C}$. The cell pellet was suspended in TBSM buffer (50 mM Tris-Cl, $150 \mathrm{mM} \mathrm{NaCl}, 2 \mathrm{mM} \mathrm{MgCl}_{2}, \mathrm{pH}$ $8.0,15 \mathrm{ml}$ per roller bottle) before disruption by microfluidization (three passes, model HC 2000; Microfluidics Corporation, Newton, MA, USA). Cell debris was removed by centrifugation $\left(2000 \mathrm{~g}, 30 \mathrm{~min}, 4^{\circ} \mathrm{C}\right)$, and the supernatant was adjusted to $25 \mathrm{mM} \mathrm{CaCl}_{2}$ by adding the appropriate amount of a $1 \mathrm{M}$ stock solution. After $1 \mathrm{~h}$ incubation at $4{ }^{\circ} \mathrm{C}$, the resultant precipitate was removed by centrifugation $\left(2000 \mathrm{~g}, 30 \mathrm{~min}, 4^{\circ} \mathrm{C}\right)$, and the supernatant was digested with benzonase $(100 \mathrm{U} / \mathrm{ml})$ for $1 \mathrm{~h}$ at $37^{\circ} \mathrm{C}$. Vector particles were then precipitated for $2 \mathrm{~h}$ at $0^{\circ} \mathrm{C}$ with $8 \%$ polyethylene glycol 8000 (in $650 \mathrm{mM} \mathrm{NaCl}$ ) and collected by centrifugation $\left(2000 \mathrm{~g}, 30 \mathrm{~min}, 0^{\circ} \mathrm{C}\right)$. The pellet was completely dissolved in $50 \mathrm{mM}$ HEPES, $150 \mathrm{mM} \mathrm{NaCl}, 20 \mathrm{~mm}$ ethylenediaminetetraacetic acid (EDTA) and 1\% SArcosyl, pH 8.0, containing $10 \mu \mathrm{g} / \mathrm{ml}$ RNase A (2 ml per roller bottle) and then applied to a $\mathrm{CsCl}$ step gradient consisting of $5 \mathrm{ml}$ of $1.5 \mathrm{~g} \mathrm{CsCl} / \mathrm{ml}$ for the bottom layer and $10 \mathrm{ml}$ of $1.3 \mathrm{~g} \mathrm{CsCl} / \mathrm{ml}$ for the middle layer; $22 \mathrm{ml}$ of sample was used (in $25 \times 89 \mathrm{~mm}$ polyallomer tubes, spun in an SW28 rotor at 28000 r.p.m. for $17 \mathrm{~h}$ at $20^{\circ} \mathrm{C}$ ). The lower full capsid band was identified visually and collected with an 18-gauge hypodermic needle and a $10 \mathrm{ml}$ syringe through the side of the tube. The vector-containing solution was again centrifuged on a linear $\mathrm{CsCl}$ gradient $(14 \times 95 \mathrm{~mm}$ polyallomer tubes, spun in an SW40 rotor at 38k r.p.m. for $24 \mathrm{~h}$ at $20^{\circ} \mathrm{C}$ ). The full capsid band was collected with a hypodermic needle, dialyzed against phosphatebuffered saline (PBS) containing 5\% sorbitol and $0.1 \%$ Tween 80, $\mathrm{pH} 7.4$, and stored frozen at $-80^{\circ} \mathrm{C}$. Vector genome titers were determined by quantitative real-time PCR and slot blot analyses as described. ${ }^{13,30}$

\section{Isolation of mouse bone marrow cells and DC culture} Isolation of mouse bone marrow precursors and generation of bone marrow-derived DC were performed by a modified method of Inaba et al. ${ }^{39}$ Briefly, bone marrow single-cell suspensions obtained from C57BL/6 mice were depleted of red cells by hypotonic lysis. To generate DC, the precursors were cultured in RPMI-1640 plus $10 \%$ FCS, $100 \mathrm{ng} / \mathrm{ml}$ recombinant mouse IL-4 (Peprotech, Rocky Hill, NJ, USA) and $20 \mathrm{ng} / \mathrm{ml}$ recombinant mouse GM-CSF (Peprotech), in 12-well tissue culture dishes (Corning) at a density of 200000 cells/well.

\section{Recombinant AAV transduction and DC maturation}

Transduction of bone marrow cells cultured in the presence of IL-4 and GM-CSF was performed on days 2, 4 and 7. Prior to transduction at each time point, medium was collected by gentle aspiration leaving the adherent cells intact. The loose cells in the supernatant were collected by brief centrifugation. After washing once with Opti-MEMI medium (Gibco-BRL), the nonadherent cells were added to respective adherent population. Infection of rAAV was performed in $150 \mu \mathrm{l}$ of Opti-MEMI for $2 \mathrm{~h}$ at $37^{\circ} \mathrm{C}$ after which $2 \mathrm{ml}$ of complete medium with cytokines was added and the cells cultured further. On day 8, some cultures received $1 \mu \mathrm{M} \mathrm{CpG}$ ODN and $1 \mu \mathrm{g} / \mathrm{ml}$ anti-mouse CD40 antibody. After $24 \mathrm{~h}, \mathrm{DC}$ were harvested as the nonadherent and loosely adherent cells and used in studies described below.

\section{Immunocytochemistry}

DC were washed three times in PBS and approximately 50000 cells from each treatment were deposited on microscopic slides by cytospin and air-dried. Cells were fixed in $10 \%$ buffered formaldehyde for $30 \mathrm{~min}$ at room temperature and washed in PBS. Immunostaining of the cells was performed by incubating with biotin-labeled human CEA monoclonal antibody COL-1 at a concentration of $1 \mu \mathrm{g} / \mathrm{ml}$ in PBS containing $1 \%$ goat serum for $20 \mathrm{~min}$ at room temperature. A control slide was incubated in PBS containing $1 \%$ goat serum without COL-1. Following incubation, slides were washed three times with PBS and incubated with peroxidase-labeled streptavidin (BioGenex) for $20 \mathrm{~min}$. Slides were again washed five times with PBS and color development was accomplished by incubation with DAB substrate solution (BioGenex) for $15 \mathrm{~min}$. Slides were washed with distilled water and minimally counterstained with hematoxylin before mounting. CEA expression was analyzed on a Olympus microscope and images photographed. To determine $\beta$-Gal expression, $150 \mu \mathrm{g} / \mathrm{ml}$ X-gal was directly added to the cultures and positive cells were visualized by microscopy.

\section{Flow cytometry}

DC were analyzed by fluorescence flow cytometry to determine phenotype and purity using FITC-conjugated monoclonal antibodies specific for mouse CD11c, CD54, CD80 and CD86. A total of 100000 cells were incubated with antibodies at the concentrations recommended by the manufacturers plus $10 \mu \mathrm{g} / \mathrm{ml}$ of aggregated IgG to block Fc receptors, in PBS containing 1\% bovine serum albumin (BSA), on ice for $30 \mathrm{~min}$. Cells were washed once with 10 volumes of PBS+1\% BSA and resuspended in PBS $+1 \%$ paraformaldehyde prior to analysis. All analyses included unstained DC and DC stained with an irrelevant isotype-matched FITC-labeled antibody. Analyses were performed in the Flow Cytometry Core Facility of the UAB Center for AIDS Research.

\section{Real-time PCR for vector genome}

Total DNA was isolated from DC following rAAV transduction as described. ${ }^{12}$ Quantitative real-time PCR was carried out using CMV promoter-specific primers in a Biorad Icycler (Optical Module). Reactions were performed using the LightCycler-FastStart DNA Master SYBR Green system (Roche Molecular Biochemicals, Mannheim, Germany) in a final volume of $25 \mu \mathrm{l}$, consisting of $0.5 \mu \mathrm{l}$ of each primer $(0.5 \mathrm{pM}), 12.5 \mu \mathrm{l}$ of $2 \times$ supermix containing reaction buffer, Fast-start Tag DNA double strand-specified SYBR Green I dye, $5.5 \mu \mathrm{l}$ $\mathrm{H}_{2} \mathrm{O}$ and $5 \mu \mathrm{l}(0.5 \mu \mathrm{g})$ of template DNA. The following primers were used for amplification of vector-specific sequences and endogenous mouse GAPDH gene: CMV promoter forward: 5'-CAATGGGTGGAGTATTTACGG-3', CMV reverse: 5'-GTCAATAGGGGGCGGACT-3'; GAPDH forward: 5'-CCCACTCTTCCACCTTC GATGC-3', GAPDH reverse: 5'-GAGGTCCACCACCCTGTTGCTGT-3'. PCR was performed with a $3 \mathrm{~min}$ preincubation at $95^{\circ} \mathrm{C}$ followed by 45 cycles of $15 \mathrm{~s}$ denaturation at $95^{\circ} \mathrm{C}$, and $30 \mathrm{~s}$ annealing and extension at $57^{\circ} \mathrm{C}$. PCR products were subjected to melting curve analysis using the light cycler system to exclude amplification of nonspecific products. Values obtained from amplification of vector-specific 
sequences from each sample were normalized to copy number of GAPDH gene amplification from the same sample to derive the relative vector copy number per cell.

\section{Microarray analysis}

Total RNA was isolated from DC cultures using the TRIzol reagent (Gibco, BRL). Preparation of cRNA, hybridization and scanning of the microarrays were performed according to the manufacturer's protocol (Affymetrix, Santa Clara, CA, USA). Briefly, 12-15 $\mu \mathrm{g}$ of RNA was converted to double-stranded cDNA by reverse transcription using a cDNA synthesis kit with oligo-dT primer containing a T7 RNA polymerase promoter site added $3^{\prime}$ of poly(T). After second-strand synthesis, labeled cRNAs were generated from the cDNA sample by in vitro transcription reaction supplemented with the RNA transcription labeling kit. The labeled cRNA was purified using RNeasy spin columns and denatured at $94^{\circ} \mathrm{C}$ before hybridization. Labeled cRNA was hybridized to the Affymetrix Mouse 4302.0 array while rotating at 60 r.p.m. for $16 \mathrm{~h}$ at $45^{\circ} \mathrm{C}$. After hybridization, the microarray was washed using the Affymetrix Fluidics Station in buffer containing biotinylated anti-streptavidin-PE for $10 \mathrm{~min}$ at $25^{\circ} \mathrm{C}$. Subsequently, the microarray was washed, restained with streptavidin-PE and washed again before measuring fluorescence at $570 \mathrm{~nm}$ in an Affymetrix scanner. Data were normalized by global scaling using the Affymetrix software. The microarray analysis was performed in UAB Comprehensive Cancer Center Gene Expression Facility.

\section{In vivo studies}

Mice were vaccinated subcutaneously with 100000 DC, which were mock-transduced or transduced with rAAV6- $\beta$-Gal or CEA, for a total of two injections with an interval of 2 weeks. Harvested DC were resuspended in a volume of $200 \mu \mathrm{l}$ Opti-MEMI and $100 \mu \mathrm{l}$ was injected bilaterally in the subinguinal area. Blood samples were collected 2 weeks after the second vaccination.

\section{ELISA}

Serum antibody titers against human CEA and AAV6 capsid were determined by ELISA. Briefly, for CEA antibody, 96-well EIA plates (Costar 3590) were coated with human CEA protein (Fitzgerld) at a concentration of $1 \mu \mathrm{g} / \mathrm{ml}$ in borate saline (BS), $\mathrm{pH} 8.4$, for $4 \mathrm{~h}$ at room temperature, and then blocked for $90 \mathrm{~min}$ with BS plus $1 \%(\mathrm{w} / \mathrm{v})$ BSA (BS-BSA). Serial three-fold dilutions of mouse serum in BS-BSA (1:50-1:109 350) were added to duplicate wells and incubated overnight at $4{ }^{\circ} \mathrm{C}$. Plates were washed with PBS+0.05\% (v/v) Tween 20 (PBST) and incubated with either AP-conjugated goat antimouse IgG or anti-IgM diluted 1:2000 in BS-BSA for $4 \mathrm{~h}$ at room temperature. After washing, AP substrate in diethanolamine buffer, $\mathrm{pH}$ 9.0, was added and incubated for $20 \mathrm{~min}$ at room temperature. Absorbance was measured at $405 \mathrm{~nm}$ on a VersaMax microplate reader using SoftMax Pro software (Molecular Devices, Sunnyvale, CA, USA). Absorbance on CEA-coated plates was corrected for absorbance on parallel plates coated with ovalbumin (Sigma). COL-1 mouse monoclonal $\gamma 2 \mathrm{a}$ antibody to CEA (Neomarkers, Freemont, CA, USA) was used as a positive control. To determine the IgG subtypes, AP-conjugated goat anti-mouse IgG1, IgG2a, IgG2b or IgG3 secondary antibodies were used in separate ELISA.

An ELISA for determining antibody to AAV6 capsids was developed in our laboratory. Briefly, $5 \times 10^{8}$ particles of AAV6 per well in $100 \mu \mathrm{l}$ of BS were coated onto EIA plates overnight at $4^{\circ} \mathrm{C}$. Plates were blocked with BS-BSA for $90 \mathrm{~min}$, washed and serial three-fold dilutions of mouse sera diluted in BS-BSA were added and incubated at room temperature for $6 \mathrm{~h}$. Plates were washed five times with PBST, and APconjugated goat anti-mouse IgG was added and incubated overnight at $4^{\circ} \mathrm{C}$. Finally, plates were washed five times in PBST and AP substrate was added. Substrate reaction was stopped after $20 \mathrm{~min}$ at room temperature and the OD at $405 \mathrm{~nm}$ was measured in the ELISA plate reader as above.

Cytokine release assay for cellular immune response Single-cell suspensions of splenocytes were prepared by mincing and forcing mouse spleen tissue through a $100 \mu \mathrm{m}$ sterile nylon strainer (Falcon 35-2360) in PBS. Erythrocytes were removed by hypotonic lysis and cells cultured in RPMI-1640 medium $+10 \%$ FCS, $4 \mathrm{mM}$ L-glutamine and $12.5 \mu \mathrm{M} \quad \beta$-mercaptoethanol at $1 \times$ $10^{5}$ cells/well in round-bottom 96-well plates (Linbro 75-042-05). Cells were cultured in the presence of $50 \mu \mathrm{g} /$ $\mathrm{ml}$ purified human CEA (Aspen Bio, Castle Rock, CO, USA) or as negative controls, media alone or $50 \mu \mathrm{g} / \mathrm{ml}$ ovalbumin. After 3 days, culture supernatants were collected and assayed for mouse IFN- $\gamma$ using ELISA kits (Biosource International, Camarillo, CA, USA) according to the manufacturer's instructions. ${ }^{10}$

\section{Neutralizing antibody assay}

Serum samples obtained from groups of mice 15 days after final DC vaccination were pooled and diluted with PBS. Then, 10-fold dilutions of the pooled sera were incubated with $5 \times 10^{8}$ particles of rAAV- $\beta$-Gal (serotypes 1-6) at room temperature for $30 \mathrm{~min}$, following which the mixture was used to infect HEK293 cells in 24-well plates for $45 \mathrm{~min}$ at $37^{\circ} \mathrm{C}$. The infection medium was removed and cells were washed four times with PBS and cultured in complete medium for $48 \mathrm{~h}$. Cultures were lysed, and $\beta$-Gal enzymatic activity was determined by a colorimetric method. Each assay was performed in duplicate. The values were presented as percentage of $\beta$-Gal activity compared to transduction of an equal amount of virus without preincubation.

\section{Acknowledgements}

Financial support from the National Institutes of Health Grants R01CA90850, R01CA98817 and P50 CA89019 is gratefully acknowledged.

\section{References}

1 Buning H, Nicklin SA, Perabo L, Hallek M, Baker AH. AAVbased gene transfer. Curr Opin Mol Ther 2003; 5: 367-375.

2 Flotte TR. Gene therapy progress and prospects: recombinant adeno-associated virus (rAAV) vectors. Gene Therapy 2004; 11: 805-810. 
3 Stilwell JL, Samulski RJ. Adeno-associated virus vectors for therapeutic gene transfer. Biotechniques 2003; 34: 148-150.

4 Flotte TR, Brantly ML, Spencer LT, Byrne BJ, Spencer CT, Baker $\mathrm{DJ}$ et al. Phase I trial of intramuscular injection of a recombinant adeno-associated virus alpha 1-antitrypsin (rAAV2-CB-hAAT) gene vector to AAT-deficient adults. Hum Gene Ther 2004; 15: 93-128.

5 Kay MA, Manno CS, Ragni MV, Larson PJ, Couto LB, McClelland $\mathrm{A}$ et al. Evidence for gene transfer and expression of factor IX in haemophilia B patients treated with an AAV vector. Nat Genet 2000; 24: 257-261.

6 Moss RB, Rodman D, Spencer LT, Aitken ML, Zeitlin PL, Waltz $\mathrm{D}$ et al. Repeated adeno-associated virus serotype 2 aerosolmediated cystic fibrosis transmembrane regulator gene transfer to the lungs of patients with cystic fibrosis: a multicenter, double-blind, placebo-controlled trial. Chest 2004; 125: 509-521.

7 Haigwood NL, Montefiori DC, Sutton WF, McClure J, Watson AJ, Voss $\mathrm{G}$ et al. Passive immunotherapy in simian immunodeficiency virus-infected macaques accelerates the development of neutralizing antibodies. J Virol 2004; 78: 5983-5995.

8 Johnson PR, Schnepp BC, Connell MJ, Rohne D, Robinson S, Krivulka GR et al. Novel adeno-associated virus vector vaccine restricts replication of simian immunodeficiency virus in macaques. J Virol 2005; 79: 955-965.

9 Ponnazhagan S. Adeno-associated virus vectors for genetic immunization. J Immunol Res 2002; 26: 247-253.

10 Ponnazhagan S, Mahendra G, Lima J, Aldrich WA, Jenkins CB, Ren $\mathrm{C}$ et al. Augmentation of anti-tumor activity of a recombinant adeno-associated virus carcinoembryonic antigen vaccine with plasmid adjuvants. Hum Gene Ther 2004; 15: 856-864.

11 Banchereau J, Steinman RM. Dendritic cells and the control of the immunity. Nature 1998; 392: 245-252.

12 Ponnazhagan S, Mahendra G, Curiel DT, Shaw DR. Adenoassociated virus-mediated transduction of human monocytederived dendritic cells: implications for ex vivo immunotherapy. J Virol 2001; 75: 9493-9501.

13 Figdor CG, de Vries IJ, Lesterhuis WJ, Melief CJ. Dendritic cell immunotherapy: mapping the way. Nat Med 2004; 10: 475-480.

14 Jooss K, Yang $\mathrm{Y}$, Fisher KJ, Wilson JM. Transduction of dendritic cells by DNA viral vectors directs the immune response to transgene products in muscle fibers. J Virol 1998; 72: 4212-4223.

15 Xiao W, Chirmule N, Schnell MA, Tazelaar J, Hughes JV, Wilson JM. Route of administration determines induction of T-cellindependent humoral responses to adeno-associated virus vectors. Mol Ther 2000; 1: 323-329.

16 Burger C, Gorbatyuk OS, Velardo MJ, Peden CS, Williams P, Zolotukhin $\mathrm{S}$ et al. Recombinant AAV viral vectors pseudotyped with viral capsids from serotypes 1,2, and 5 display differential efficiency and cell tropism after delivery to different regions of the central nervous system. Mol Ther 2004; 10: 302-317.

17 Halbert CL, Rutledge EA, Allen JM, Russell DW, Miller AD. Repeat transduction in the mouse lung by using adenoassociated virus vectors with different serotypes. J Virol 2000; 74: 1524-1532.

18 Louboutin JP, Wang L, Wilson JM. Gene transfer into skeletal muscle using novel AAV serotypes. J Gene Med 2005; 7: 442-451.

19 Rabinowitz JE, Rolling F, Li C, Conrath H, Xiao W, Xiao X et al. Cross-packaging of a single adeno-associated virus (AAV) type 2 vector genome into multiple AAV serotypes enables transduction with broad specificity. J Virol 2002; 76: 791-801.

20 McCarty DM, Monahan PE, Samulski RJ. Self-complementary recombinant adeno-associated virus (scAAV) vectors promote efficient transduction independently of DNA synthesis. Gene Therapy 2001; 8: 1248-1254.
21 Wang Z, Ma HI, Li J, Sun L, Zhang J, Xiao X. Rapid and highly efficient transduction by double-stranded adeno-associated virus vectors in vitro and in vivo. Gene Therapy 2003; 10: 2105-2111.

22 Lima J, Jenkins C, Guerrero A, Triozzi PL, Shaw DR, Strong TV. A DNA vaccine encoding genetic fusions of carcinoembryonic antigen (CEA) and granulocyte/macrophage colony-stimulating factor (GM-CSF). Vaccine 2005; 23: 1273-1283.

23 O'Toole PJ, Inoue T, Emerson L, Morrison IE, Mackie AR, Cherry RJ. Id proteins negatively regulate basic helix-loop-helix transcription factor function by disrupting subnuclear compartmentalization. J Biol Chem 2003; 278: 45770-45776.

24 Conry RM, LoBuglio AF, Kantor J, Schlom J, Loechel F, Moore SE et al. Immune response to a carcinoembryonic antigen polynucleotide vaccine. Cancer Res 1994; 54: 1164-1168.

25 Banchereau JF, Briere C, Caux J, Davoust S, Lebecque YJ, Liu B et al. Immunobiology of dendritic cells. Annu Rev Imunol 2000; 18: 767-811.

26 Mellman I, Steinman RM. Dendritic cells: specialized and regulated antigen processing machines. Cell 2001; 106: 255-258.

27 Steinman RM, Pope M. Exploiting dendritic cells to improve vaccine efficacy. J Clin Invest 2002; 109: 1519-1526.

28 Zhou Y, Bosch ML, Salgaller ML. Current methods for loading dendritic cells with tumor antigen for the induction of antitumor immunity. J Immunother 2002; 25: 289-303.

29 Roth MD, Cheng Q, Harui A, Basak SK, Mitani K, Low TA et al. Helper-dependent adenoviral vectors efficiently express transgenes in human dendritic cells but still stimulate antiviral immune responses. J Immunol 2002; 169: 4651-4656.

30 Sarukhan A, Camugli S, Gjata B, von Boehmer H, Danos O, Jooss K. Successful interference with cellular immune responses to immunogenic proteins encoded by recombinant viral vectors. J Virol 2001; 75: 269-277.

31 Rutledge EA, Halbert CL, Russell DW. Infectious clones and vectors derived from adeno-associated virus (AAV) serotypes other than AAV type 2. J Virol 1998; 72: 309-319.

32 Gregorevic P, Blankinship MJ, Allen JM, Crawford RW, Meuse L, Miller DG et al. Systemic delivery of genes to striated muscles using adeno-associated viral vectors. Nat Med 2004; 10: 828-834.

33 Halbert CL, Allen JM, Miller AD. Adeno-associated virus type 6 (AAV6) vectors mediate efficient transduction of airway epithelial cells in mouse lungs compared to that of AAV2 vectors. J Virol 2001; 75: 6615-6624.

34 Bartlett JS, Wilcher R, Samulski RJ. Infectious entry pathway of adeno-associated virus and adeno-associated virus vectors. J Virol 2000; 74: 2777-2785.

35 Hansen J, Qing K, Srivastava A. Adeno-associated virus type 2-mediated gene transfer: altered endocytic processing enhances transduction efficiency in murine fibroblasts. J Virol 2001; 75: 4080-4090.

36 Sanlioglu S, Monick MM, Luleci G, Hunninghake GW, Engelhardt JF. Rate limiting steps of AAV transduction and implications for human gene therapy. Curr Gene Ther 2001; 1: 137-147.

37 Ferlazzo G, Pack M, Thomas D, Paludan C, Schmid D, Strowig T et al. Distinct roles of IL-12 and IL-15 in human natural killer cell activation by dendritic cells from secondary lymphoid organs. Proc Natl Acad Sci USA 2004; 101: 16606-16611.

38 Ponnazhagan S, Mahendra G, Kumar S, Shaw DR, Meleth S, Stockardt $\mathrm{R}$ et al. Adeno-associated virus 2-mediated antiangiogenic cancer gene therapy: long-term efficacy of a vector encoding angiostatin and endostatin over vectors encoding a single factor. Cancer Res 2004; 64: 1781-1787.

39 Inaba K, Inaba M, Romani N, Aya H, Deguchi M, Ikehara S et al. Generation of large numbers of dendritic cells from mouse bone marrow cultures supplemented with granulocyte/macrophage colony-stimulating factor. J Exp Med 1992; 176: 1693-1702. 